\title{
PENGARUH MEDIA SOSIAL UNTUK MENINGKATKAN PENGETAHUAN DAN SIKAP REMAJA TENTANG HIV E AIDS DI KOTA PAREPARE
}

\section{THE EFFECT OF SOCIAL MEDIA TO IMPROVE ADOLESCENT KNOWLEDGE AND ATTITUDE OF HIV \& AIDS IN PAREPARE CITY}

\author{
Sitti Aisyah ${ }^{1}$, Muhammad Syafar ${ }^{1}$, Ridwan Amiruddin $^{2}$ \\ ${ }^{1}$ Departemen Promosi Kesehatan, Fakultas Kesehatan Masyarakat, Universitas Hasanuddin \\ ${ }^{2}$ Departemen Epidemiologi, Fakultas Kesehatan Masyarakat, Universitas Hasanuddin \\ Email Korespondensi: nizamaisyah3@gmail.com
}

\begin{abstract}
ABSTRAK
Pertambahan jumlah kasus baru HIV \& AIDS masih menjadi hal yang mengkhawatirkan terutama dikalangan remaja. Penelitian ini bertujuan untuk mengetahui pengaruh intervensi melalui media sosial oleh peer educator terhadap peningkatan pengetahuan dan sikap remaja tentang HIV \& AIDS. Penelitian ini adalah quasi eksperimen dengan rancangan randomized pretest posttest control group. Jumlah sampel sebanyak 100 orang yang berasal dari siswa-siswi SMAN 4 Parepare sebagai kelompok intervensi dan SMAN 2 Parepare sebagai kelompok kontrol. Pengambilan sampel dilakukan secara simple random sampling. Analisis skor pengetahuan dan sikap responden antara pretest dan postest menggunakan uji non parametrik two related sample( wilcoxon) dan uji t sampel berpasangan. Untuk membandingkan pengetahuan dan sikap responden kelompok intervensi dan kontrol menggunakan uji non parametrik two independent sample (Mann- Whitney) dan uji t sampel tidak berpasangan. Batas kemaknaan (nilai alpha) ditetapkan 5\% (0,05). Hasil penelitian menunjukkan ada pengaruh intervensi melalui media sosial oleh peer educator dalam meningkatkan pengetahuan $\mathrm{p}=0,000(\mathrm{p}<0,05)$ dan sikap positif $\mathrm{p}=0,000(\mathrm{p}<0,05)$ responden mengenai HIV \& AIDS. Ada perbedaan pengetahuan dan sikap responden mengenai HIV \& AIDS setelah diintervensi melalui media sosial dibandingkan yang tidak diintervensi $\mathrm{p}=0,000 \quad(\mathrm{p}<0,05)$. Kesimpulan dari penelitian ini adalah intervensi melalui media sosial oleh peer educator berpengaruh terhadap peningkatan pengetahuan dan sikap remaja tentang HIV \& AIDS. Kelompok yang diintervensi oleh Peer Educator melalui media sosial memiliki skor pengetahuan dan sikap lebih baik daripada kelompok yang tidak diintervensi.
\end{abstract}

Kata kunci :Media Sosial, Peer Educator, HIV \& AIDS.

\section{ABSTRACT}

The increasing number of new cases of HIV \& AIDS is still considering to be worried especially among adolescents. This study aims to determine the effect of intervention through social media by peer educator on increasing knowledge and attitude of adolescent about HIV \& AIDS. This research is quasi experiment with randomized pretest posttest control group design. The sample size were 100 people from students of SMAN 4 Parepare as intervention group and SMAN 2 Parepare as control group. Sampling was done by simple random sampling. Analysis of knowledge scores and attitudes of respondents between pretest and posttest using non parametric two related sample (wilcoxon) and paired sample t test. To compare the knowledge and attitudes of the intervention and control group respondents. The research using non independent parametric two independent sample (Mann-Whitney) test and unpaired sample $t$ test. The significance limit (alpha value) is set at 5\% (0.05). The results showed that there was an influence of intervention through social media by peer educators in increasing knowledge $p=0,000(p<0,05)$ and positive attitude $p=0,000(p<0,05)$ respondents regarding HIV \& AIDS. There were differences in respondents knowledge and attitudes about HIV \& AIDS after intervening through social media compared to those who were not intervened $p=0,000(p<0.05)$. This study concludes that intervention through social media by peer educator have an effect on to increase knowledge and attitude of adolescent about HIV \& AIDS. The group that was intervened by Peer Educator through social media had a better score of knowledge and attitude than the group that was not intervened. Keywords:Social Media, Peer Educator, HIV \& AIDS 


\section{PENDAHULUAN}

Pertambahan jumlah kasus baru HIV \& AIDS (Human Immunodeficiency Virus \& Acquired Immune Deficiency Syndrome) masih menjadi hal yang mengkhawatirkan. Lebih dari 70 juta orang telah terinfeksi virus HIV sejak awal ditemukannya epidemi dan sekitar 35 juta orang meninggal karena HIV (WHO, 2017). Jumlah kumulatif kasus infeksi HIV yang dilaporkan provinsi sampai Maret 2017 di Indonesia adalah 242.699 orang. Jumlah total ODHA (orang dengan HIV \& AIDS) adalah sebanyak 87.453 orang (Ditjen P2P Kemenkes RI, 2017). Jumlah pengidap HIV berusia 15 - 24 tahun dari tahun 2006 sampai dengan 2017 di Kota Parepare adalah sejumlah 61 orang. Total pravalensi HIV \& AIDS sampai saat ini telah mencapai 330 orang menjadikannya tertinggi kedua setelah Kota Makassar. Angka tersebut mengalami peningkatan secara signifikan dari tahun 2005 yang hanya terdata 3 orang yang terdeteksi (Dinas Kesehatan Kota Parepare, 2017).

Upaya pencegahan pada tingkat remaja sangat penting dilakukan. Masa remaja merupakan periode yang rawan ketika keputusan-keputusan untuk mempraktekkan perilaku seksual berisiko dan berpotensi menyebabkan penularan HIV \& AIDS dan penyakit menular seksual lainnya sangat mungkin terjadi. Proses pematangan seksual, perkembangan pada biologis, anatomi dan fisiologi, dan kemampuan reproduksi, yang menandai transisi dari masa kanak-kanak kemasa remaja terjadi dimasa ini (Moshman, 2014). Remaja yang memiliki pengetahuan dan sikap yang kurang akan memiliki perilaku seksual tak wajar tentu meningkatkan penularan HIV \& AIDS. Hasil survei situasi kesehatan reproduksi remaja tahun 2012 menunjukkan bahwa pengetahuan remaja di Indonesia mengenai HIV \& AIDS sangatlah kurang sebab hanya 9,9\% remaja perempuan dan 10,6\% remaja lelaki yang memiliki pengetahuan komprehensif mengenai HIV \& AIDS. Oleh karena itu sangat perlu dilakukan pendidikan kesehatan kepada remaja sebagai upaya pencegahan penyakit HIV \& AIDS (Survei Demografi dan Kesehatan Indonesia, 2012).

Salah satu metode pendidikan kesehatan yang dapat dilakukan yakni peer education atau pendidik sebaya. Remaja gampang terpengaruh dalam pergaulan, mereka cenderung akan meniru sikap dari teman sebayanya. Metode peer educator dalam meningkatkan pengetahuan dan sikap tentang pencegahan HIV \& AIDS, dianggap lebih efektif dibandingkan metode ceramah 
interaktif (Haerana dkk., 2015). Menurut data SDKI 2012 teman diskusi dan sumber informasi kesehatan reproduksi yang disukai remaja usia 15-19 tahun adalah teman sebaya bagi remaja pria $(33,3 \%)$ dan ibu bagi remaja putri $(40 \%)$. Intervensi pendidikan sebaya (peer educator) biasa digunakan untuk program pencegahan HIV dan penyakit infeksi menular lainnya (Tolli, 2012). Peer education adalah metode yang efektif untuk mempromosikan perilaku sehat di kalangan remaja (Abdi dkk., 2013).

Berbagai metode pendidikan sebaya dapat dilakukan, melalui strategi interaktif seperti kelompok kecil presentasi atau ceramah, permainan peran, permainan interaktif, menggunakan media yakni leaflet atau lembar balik dan pemutaran film. Metode lain yang patut dicoba adalah melalui media sosial. Media sosial bisa jadi alat yang ampuh untuk pendidikan dan advokasi mengenai masalah kesehatan masyarakat (Farnan dkk., 2013). Meluasnya penggunaan media sosial juga dapat mempengaruhi perilaku masyarakat dan tujuan kesehatan melalui penguatan sosial, karena manusia adalah spesies yang sangat sosial dan sering dipengaruhi oleh rekan mereka (George dkk., 2013). Kementerian Komunikasi dan Informasi melakukan survey nasional terhadap penggunaan internet oleh remaja
Indonesia bekerja sama dengan UNICEF, The Berkman Center for Internet and Society dan Harvard University. Hasilnya menunjukkan bahwa sebanyak 30 juta remaja Indonesia mengakses internet secara reguler. Hampir setengah dari 75 juta pengguna internet Indonesia adalah remaja (Kominfo, 2014). Selain itu penelitian yang dilakukan oleh Nugrohoi (2014), tentang pengaruh pemberian materi kesehatan reproduksi melalui grup facebook terhadap pengetahuan remaja di Indonesia menyimpulkan bahwa ada perbedaan yang signifikan pada pengetahuan responden setelah intervensi dibandingkan pengetahuan responden sebelum intervensi (Nugrohoi, 2014). Penelitian ini bertujuan untuk mengetahui pengaruh intervensi melalui media sosial oleh peer educator terhadap peningkatan pengetahuan dan sikap remaja tentang HIV \& AIDS.

\section{BAHAN DAN METODE}

\section{Lokasi dan Rancangan Penelitian}

Penelitian dilaksanakan di dua lokasi yakni SMA Negeri 2 dan SMA Negeri 4 di Kota Parepare. Berdasarkan observasi awal kedua sekolah terletak di kecamatan berbeda sehingga intervensi yang dilakukan dapat dikontrol dan mengurangi bias efek edukasi. Pemilihan sekolah juga berdasarkan 
Aisyah, 2020

observasi awal yakni sekolah tersebut memiliki peer educator yang aktif di dalam komunitas Genre. Status akreditasi SMA Negeri 2 adalah A, beralamat di Jl Jenderal Sudirman No. 31 Kelurahan Cappagalung, Kecamatan Bacukiki Barat yang termasuk daerah ramai penduduk. Sedangkan Status SMA Negeri 4 berakreditasi A beralamat di J1. Lasiming no. 22 Kelurahan Ujung Bulu Kecamatan Ujung. Lokasinya juga termasuk daerah ramai penduduk. Jenis penelitian adalah quasi eksperimen (eksperimen semu) dengan rancangan randomized pretestpostesttcontrol group.

\section{Populasi dan Sampel}

Jumlah keseluruhan siswa SMAN 2 pada tahun ajaran 2017/2018 adalah 1218 orang (529 laki-laki dan 689 perempuan). Populasi siswa jurusan IPA di tingkat XI (sebelas) adalah sebanyak 208 orang (98 orang lakilaki dan 110 orang perempuan). Jumlah seluruh siswa SMA Negeri 4 tahun ajaran 2017/2018 adalah 823 orang, terdiri dari siswa laki-laki 333 orang dan siswa perempuan 490 orang. Sedangkan populasi siswa jurusan IPA di tingkat XI (sebelas) adalah sebanyak 180 orang.

Besar sampel diperoleh dengan menggunakan rumus besar sampel untuk penelitian analitis kategorik-numerik berpasangan. Berdasarkan perhitungan tersebut besar sampel pada masing-masing kelompok adalah sejumlah 38 orang. Namun dalam penelitian ini untuk menjaga kemungkinan berkurangnya sampel yang drop out maka sampel dicukupkan masingmasing 50 orang sehingga totalnya 100 orang sampel. Teknik pengambilan sampel dilakukan secara Simple Random Sampling yakni pengambilan sampel dilakukan tanpa memperhatikan strata yang ada. Namun untuk menjamin homogenitas maka populasi yang diambil hanya kelas XI IPA.

\section{Metode Pengumpulan Data}

Pengumpulan data dilakukan langsung oleh peneliti, Data yang dikumpulkan merupakan data primer dan data sekunder. Data primer diperoleh dari instrumen penelitian (kuesioner) yang telah diisi oleh responden. Data sekunder diperoleh dari Dinas Kependudukan dan Keluarga Berencana, Dinas Kesehatan serta dari sekolah yang dilakukan intervensi yaitu SMA Negeri 4 dan sekolah yang dijadikan kontrol yakni SMA Negeri 2 kota Parepare. Pengumpulan data primer meliputi nilai pengetahuan dan sikap tentang kesehatan reproduksi remaja pretestdan post test dilakukan oleh peneliti. Pengetahuan diukur dengan mengisi kuesioner yang berisi 15 pertanyaan. Sikap diukur dengan mengisi kuesioner yang berisi 15 pertanyaan. Adapun 
karakteristik responden yang meliputi jenis kelamin, usia, pendidikan orang tua (ayah), pekerjaan orang tua (ayah), dan sumber informasi pertama tentang HIV \& AIDS, media sosial yang paling sering digunakan, alat untuk mengakses media sosial, waktu yang dihabiskan untuk membuka media sosial, serta biaya yang digunakan untuk membeli kuota perbulan.

\section{Analisis Data}

Uji beda dua sampel berpasangan berguna untuk melihat perbedaan nilai skor pengetahuan dan sikap responden sebelum intervensi (pretest) dan setelah intervensi (postest). Sebelumnya dilakukan uji normalitas distribusi data, apabila data terdistribusi normal maka dilakukan uji $\mathrm{t}$ sampel berpasangan, apabila data tidak terdistribusi normal maka dilakukan uji non parametrik two related sample yakni uji wilcoxon. Untuk melihat perbandingan skor pengetahuan dan sikap responden antara kelompok intervensi dan kelompok kontrol maka dilakukan uji beda dua sampel bebas. Sebelumnya dilakukan uji normalitas distribusi data, apabila data terdistribusi normal maka dilakukan uji t sampel tidak berpasangan, apabila data tidak terdistribusi normal maka dilakukan uji non parametrik two independent sample yakni uji MannWhitney (Stang, 2014).

\section{HASIL}

\section{Karakteristik Sampel}

Tabel 1 menunjukkan bahwa berdasarkan jenis kelamin responden yang paling banyak adalah perempuan yakni pada kelompok intervensi sejumlah 33 orang $(66 \%)$ dan kelompok kontrol sejumlah 28 orang (56\%). Sedangkan menurut usia pada kelompok intervensi seimbang yakni sebanyak 25 orang $(50 \%)$ berusia 16 tahun dan sebanyak 25 orang $(50 \%)$ berusia 17 tahun. Pada kelompok kontrol paling banyak responden berusia 16 tahun yakni sejumlah 31 orang $(62 \%)$

Karakteristik responden berdasarkan pendidikan orang tua, jenjang pendidikan SD s/d SMA yang terbanyak yaitu pada kelompok intervensi sejumlah 41 orang (82\%) dan kelompok kontrol sejumlah 39 orang (78\%). Profesi orang tua responden paling banyak bekerja sebagai wiraswasta yakni pada kelompok intervensi sejumlah 31 orang $(62 \%)$ dan kelompok kontrol sejumlah 23 orang (46\%). Sumber informasi pertama mengenai HIV \& AIDS bagi responden kebanyakan berasal dari media elektronik, pada kelompok intervensi sejumlah 27 orang 
Aisyah, 2020

(54\%) dan pada kelompok kontrol sejumlah

16 orang $(32 \%)$.

Tabel 1. Karakteristik umum responden pada kelompok Intervensi dan kelompok kontrol

\begin{tabular}{|c|c|c|c|c|}
\hline \multirow[t]{2}{*}{ Karakteristik responden } & \multicolumn{2}{|c|}{$\begin{array}{l}\text { Kelompok Intervensi } \\
\text { (SMAN 4) } n=50\end{array}$} & \multicolumn{2}{|c|}{$\begin{array}{l}\text { Kelompok Kontrol } \\
\text { (SMAN 2) } n=50\end{array}$} \\
\hline & $\mathrm{n}$ & $\%$ & $\mathrm{n}$ & $\%$ \\
\hline \multicolumn{5}{|l|}{ Jenis Kelamin } \\
\hline -Lakilaki & 17 & 34 & 22 & 44 \\
\hline -Perempuan & 33 & 66 & 28 & 56 \\
\hline \multicolumn{5}{|l|}{ Usia } \\
\hline-16 tahun & 25 & 50 & 31 & 62 \\
\hline-17 tahun & 25 & 50 & 19 & 38 \\
\hline \multicolumn{5}{|l|}{ Pendidikan orang tua } \\
\hline -SD s/d SMA & 41 & 82 & 39 & 78 \\
\hline -D3 & 3 & 6 & 0 & 0 \\
\hline -SI & 6 & 12 & 9 & 18 \\
\hline$-\mathrm{S} 2$ & 0 & 0 & 2 & 4 \\
\hline \multicolumn{5}{|l|}{ Pekerjaan orang tua } \\
\hline -PNS & 6 & 12 & 9 & 18 \\
\hline -Wiraswasta & 31 & 62 & 23 & 46 \\
\hline -Buruh & 4 & 8 & 5 & 10 \\
\hline -BUMN & 2 & 4 & 2 & 4 \\
\hline -Petani & 3 & 6 & 1 & 2 \\
\hline -IRT & 1 & 2 & 2 & 4 \\
\hline -TNI & 2 & 4 & 3 & 6 \\
\hline -Pensiunan & 1 & 2 & 3 & 6 \\
\hline -Nelayan & 0 & 0 & 2 & 4 \\
\hline
\end{tabular}

Sumber Informasi Pertama Mengenai HIV

\& AIDS

$\begin{array}{llllll}\text {-Media Cetak } & 2 & 4 & 4 & 8\end{array}$

$\begin{array}{lllll}\text {-Media Elektronik } & 27 & 54 & 16 & 32\end{array}$

$\begin{array}{lllll}\text {-Media Sosial } & 14 & 28 & 11 & 22\end{array}$

$\begin{array}{lllll}- \text { Teman sebaya } & 0 & 0 & 2 & 4\end{array}$

$\begin{array}{lllll}- \text { Tenaga Kesehatan } & 1 & 2 & 6 & 12\end{array}$

$\begin{array}{lllll}- \text { Orang tua } & 1 & 2 & 1 & 2\end{array}$

-Guru

Media Sosial yang paling sering digunakan

-Whatsapp

-Facebook

-Instagram

-Youtube

$5 \quad 10$

10

20

Akses media sosial paling sering melalui :

-Handphone milik sendiri

-Komputer pribadi/laptop

-Komputer warnet

$\begin{array}{llll}34 & 68 & 35 & 70\end{array}$

$\begin{array}{llll}2 & 4 & 4 & 8\end{array}$

$\begin{array}{llll}9 & 18 & 10 & 20\end{array}$

$5 \quad 10$

$50 \quad 100$

12

$0 \quad 0$

Waktu yang dihabiskan untuk membuka media sosial:

$\begin{array}{lcccc}\text { media sosial: } & 21 & 42 & 26 & 52 \\ \text {-Berkisar 3 jam } & 22 & 44 & 10 & 20 \\ -4 \text { s s } 6 \text { jam } & 4 & 8 & 8 & 16 \\ -7 \text { s/d } 12 \text { jam } & 3 & 6 & 6 & 12 \\ -13 \text { s/d } 16 \text { jam } & & & 6\end{array}$

Biaya yang digunakan untuk membeli

kuota perbulan: 
Aisyah, 2020

\begin{tabular}{lcccc}
\hline \hline -Dibawah 50 rb & 15 & 30 & 7 & 14 \\
$-26 \mathrm{~s} / \mathrm{d} 50 \mathrm{rb}$ & 20 & 40 & 23 & 46 \\
$-51 \mathrm{~s} / \mathrm{d} 75 \mathrm{rb}$ & 9 & 18 & 13 & 26 \\
$-76 \mathrm{~s} / \mathrm{d} 100 \mathrm{rbd}$ & 6 & 12 & 7 & 14 \\
\hline
\end{tabular}

Media sosial yang paling sering digunakan responden yaitu whatsapp, pada kelompok intervensi sebanyak 34 orang ( $68 \%$ ) yang sering menggunakannya dan kelompok kontrol sebanyak 35 orang (70\%). Media sosial tersebut paling sering diakses melalui handphone milik sendiri, yakni pada kelompok intervensi sebanyak 50 orang $(100 \%)$ dan pada kelompok kontrol sebanyak 49 orang (98\%). Waktu yang dihabiskan responden pada kelompok intervensi untuk membuka media sosial paling banyak berkisar antara 4-6 jam (44\%) sedangkan pada kelompok kontrol berkisar 3 jam (52\%). Biaya yang dihabiskan responden untuk membeli kuota perbulan bervariasi, namun kebanyakan responden mengaku menghabiskan biaya berkisar 26 s/d 50 ribu rupiah, kelompok intervensi sejumlah 20 orang $(40 \%)$ dan kelompok kontrol sebanyak 23 orang $(46 \%)$.

\section{Pengaruh intervensi terhadap pengetahuan responden}

Tabel 2 menguraikan bahwa terjadi peningkatan rata-rata skor (mean) pengetahuan tentang HIV \& AIDS pada kelompok intervensi, pada saat pretest rerata skor pengetahuan responden adalah 70,28 dengan standar deviasi 10,44 pada saat postest meningkat menjadi 99,3 dengan standar deviasi 2,54. Peningkatan nilai mean dari pretest ke postest adalah 29,02. Skor pengetahuan terendah pada saat pretest adalah 46 dan skor pengetahuan tertinggi adalah 86. Pada saat postest skor pengetahuan terendah adalah 86 dan skor pengetahuan tertinggi adalah 100 .

Tabel 2. Perbedaan skor pengetahuan pada saat pretest dan postest di SMAN 4 dan SMAN 2 Kota Parepare Tahun 2018

\begin{tabular}{lcccccc}
\hline \multirow{2}{*}{ Nilai Statistik } & \multicolumn{2}{c}{$\begin{array}{l}\text { Skor Pengetahuan } \\
\text { Pretest }\end{array}$} & Posttest & \multicolumn{2}{c}{ Beda } & \multicolumn{2}{c}{ Skor Pengetahuan } & Beda \\
& \multicolumn{2}{c}{ Kelompok Intervensi $(\mathrm{n}=50)$} & \multicolumn{3}{c}{ Kelompok Kontrol n (50) } \\
Minimum & 46 & 86 & 40 & 40 & 40 & 0 \\
Maksimum & 86 & 100 & 14 & 100 & 93 & 7 \\
Mean & 70,28 & 99,3 & 29,02 & 73,28 & 72,24 & 1,04 \\
SD & 10,44 & 2,54 & & 14,32 & 12,71 & \\
P value & \multicolumn{7}{c}{0,000} & & & 0,333 \\
\hline
\end{tabular}

Berdasarkan hasil uji statistik non parametrik two related sample yakni uji 
wilcoxon diperoleh nilai $\mathrm{p}=0,000(\mathrm{p}<0,05)$.

Hal ini menunjukkan bahwa ada perbedaan yang signifikan skor responden pada saat pretest dan postest. Sehingga dapat disimpulkan bahwa ada pengaruh intervensi melalui media sosial oleh peer educator terhadap peningkatan pengetahuan responden pada kelompok intervensi.

Skor rerata pengetahuan pada kelompok kontrol pada saat pretest adalah 73,28 dengan standar deviasi 14,32, sewaktu postest meningkat menjadi 72,24 dengan standar deviasi 12,71. Peningkatan nilai mean dari pretest ke postest relatif bernilai kecil yakni 1,04. Skor pengetahuan minimum pada saat pretest adalah 40 dan skor pengetahuan maksimum adalah 100, sedangkan pada saat postest skor pengetahuan minimum adalah 40 dan skor pengetahuan maksimum adalah 93 .
Setelah dilakukan uji t sampel berpasangan diperoleh nilai $p=0,333 \quad(p>0,05)$ hal ini mengisyaratkan bahwa tidak ada perbedaan yang signifikan rata-rata skor (mean) pengetahuan responden kelompok kontrol antara pretest dan postest.

\section{Pengaruh intervensi terhadap sikap responden}

Tabel 3 menunjukkan rata-rata skor (mean) sikap responden tentang HIV \& AIDS pada kelompok intervensi saat pretest adalah 79,76 dengan standar deviasi 6,26, sedangkan pada saat postest meningkat menjadi 93,04 dengan standar deviasi 7,33. Peningkatan nilai mean dari pretest ke postest adalah 13,28 . Skor sikap terendah pada saat pretest adalah 58 dan skor sikap tertinggi adalah 91 sedangkan pada saat postest nilai minimum 68 dan nilai makimum 100.

\section{Tabel 3. Perbedaan skor sikap pada saat pretest dan postest di SMAN 4 dan SMAN 2} Kota Parepare Tahun 2018

\begin{tabular}{|c|c|c|c|c|c|c|}
\hline \multirow{2}{*}{ Nilai Statistik } & \multicolumn{2}{|c|}{$\begin{array}{c}\text { Skor Sikap Kelompok } \\
\text { intervensi }\end{array}$} & \multirow[t]{2}{*}{ Beda } & \multicolumn{2}{|c|}{$\begin{array}{c}\text { Skor Sikap Kelompok } \\
\text { kontrol }\end{array}$} & \multirow{2}{*}{ Beda } \\
\hline & Pretest & Posttest & & Pretest & Postest & \\
\hline Minimum & 58 & 68 & 10 & 68 & 66 & 2 \\
\hline Maksimum & 91 & 100 & 9 & 93 & 96 & 3 \\
\hline Mean & 79,76 & 93,04 & 13,28 & 80,14 & 81,28 & 1,14 \\
\hline $\mathrm{SD}$ & 6,26 & 7,33 & & 6,43 & 6,46 & \\
\hline$P$ value & & 0,000 & & & & \\
\hline
\end{tabular}

Berdasarkan hasil uji $t$ sampel berpasangan diperoleh nilai $\mathrm{p}=0,000$ $(\mathrm{p}<0,05)$ menunjukkan perbedaan skor sikapnya signifikan, sehingga dapat ditarik kesimpulan bahwa ada pengaruh intervensi melalui media sosial oleh peer educator terhadap perubahan sikap responden. 
Aisyah, 2020

Responden kelompok kontrol pada saat pretest memiliki rata-rata skor (mean) sikap tentang HIV \& AIDS adalah 80,14 dengan standar deviasi 6,43 sedangkan pada saat postest meningkat menjadi 81,28 dengan standar deviasi 6,46. Peningkatan nilai mean dari pretest ke postest adalah 1,14. Skor sikap minimum pada saat pretest adalah 68 dan skor sikap maksimumi adalah 93 sedangkan pada saat postest nilai minimum 66 dan maksimum 96. Setelah dilakukan uji statistik diperoleh nilai $\mathrm{p}=0,254(\mathrm{p}>0,05)$ hal ini mengisyaratkan bahwa tidak ada perbedaan yang signifikan rata-rata skor (mean) sikap responden pada saat pretest dan postest.

\section{kelompok kontrol dan kelompok} intervensi

Tabel 4 menguraikan hasil uji t sampel tidak berpasangan pada saat pretes. Diperoleh nilai $\mathrm{p}=0,234(\mathrm{p}>0,05)$ yang menunjukkan bahwa tidak ada perbedaan yang signifikan rata-rata skor pengetahuan responden antara kelompok intervensi dan kelompok kontrol. Sedangkan hasil uji non parametrik two independent sample (Mann- Whitney) pada saat postest menunjukkan bahwa ada perbedaan yang signifikan antara pengetahuan responden kelompok intervensi dan kontrol hal ini dibuktikan dengan nilai $\mathrm{p}$ sebesar $0,000(\mathrm{p}<0,05)$.

\section{Perbandingan pengetahuan antara}

Tabel 4. Perbandingan skor pengetahuan responden antara kelompok intervensi dan kelompok kontrol di SMAN 4 dan SMAN 2 Kota Parepare tahun 2018

\begin{tabular}{|c|c|c|c|c|}
\hline \multirow[b]{2}{*}{ Nilai statistik } & \multicolumn{2}{|c|}{ Pretest } & \multicolumn{2}{|c|}{ Postest } \\
\hline & $\begin{array}{l}\text { Kelompok } \\
\text { Intervensi }\end{array}$ & $\begin{array}{c}\text { Kelompok } \\
\text { Kontrol }\end{array}$ & $\begin{array}{l}\text { Kelompok } \\
\text { Intervensi }\end{array}$ & $\begin{array}{c}\text { Kelompok } \\
\text { Kontrol }\end{array}$ \\
\hline Pengetahuan & & & & \\
\hline $\mathrm{n}$ & 50 & 50 & 50 & 50 \\
\hline mean & 70,28 & 73,28 & 99,3 & 72,24 \\
\hline Sig $(2$-tailed $)$ & \multicolumn{2}{|c|}{0,234} & \multicolumn{2}{|c|}{0.000} \\
\hline
\end{tabular}

Tabel 5. Perbandingan skor sikap responden antara kelompok intervensi dan kelompok kontrol di SMAN 4 dan SMAN 2 Kota Parepare tahun 2018

\begin{tabular}{lcccc}
\hline Nilai statistik & \multicolumn{2}{c}{ Pretest } & \multicolumn{2}{c}{ Postest } \\
& Kelompok Intervensi & Kelompok Kontrol & Kelompok Intervensi & $\begin{array}{c}\text { Kelompok } \\
\text { Kontrol }\end{array}$ \\
\hline Sikap & 50 & 50 & 50 & 50 \\
$\mathrm{n}$ & 79,76 & 80,14 & 93,04 & 81,28 \\
mean & & 0,765 & & \multicolumn{2}{c}{0,000} \\
\hline Sig(2-tailed $)$ & & & & \\
\hline
\end{tabular}

Perbandingan sikap antara kelompok kontrol dan kelompok intervensi 
Aisyah, 2020

Perbandingan skor sikap responden antara kelompok intervensi dan kelompok kontrol diuraikan pada tabel 5. Setelah dilakukan uji $\mathrm{t}$ sampel tidak berpasangan pada saat pretest maka diketahui bahwa nilai $\mathrm{p}$ adalah 0,765 (p> 0,05). Hal ini menunjukkan tidak ada perbedaan sikap yang signifikan antara kelompok intervensi dan kelompok kontrol. Setelah dilakukan uji yang sama pada saat postest didapatkan nilai $\mathrm{p}$ sebesar 0,000 $(\mathrm{p}<0,05)$. Sehingga dapat ditarik kesimpulan bahwa ada perbedaan skor sikap responden kelompok intervensi dibandingkan kelompok kontrol.

\section{PEMBAHASAN}

Hasil penelitian menunjukkan karakteristik umum responden berdasarkan jenis kelamin. Kelompok intervensi jumlah responden perempuan paling banyak yaitu sejumlah 33 orang (66\%) dan kelompok kontrol sejumlah 28 orang $(56 \%)$. Menurut usia pada kelompok intervensi seimbang yakni sebanyak 25 orang $(50 \%)$ berusia 16 tahun dan sebanyak 25 orang $(50 \%)$ berusia 17 tahun. Responden kelompok kontrol paling banyak berusia 16 tahun yakni sejumlah 31 orang (62\%).

Penelitian ini juga mengungkapkan bahwa terjadi peningkatan skor rata-rata (mean) pengetahuan responden tentang HIV \& AIDS setelah diberikan intervensi melalui media sosial oleh peer educator. Hal ini dibuktikan dengan hasil uji statistik diperoleh nilai $\mathrm{p}=0,00(\mathrm{p}<0,05)$, nilai $\mathrm{p}$ tersebut bermakna ada perbedaan yang signifikan rerata skor pengetahuan responden pada saat postest dibandingkan pretest sehingga dapat disimpulkan bahwa ada pengaruh intervensi melalui media sosial oleh peer educator terhadap peningkatan pengetahuan responden tentang HIV \& AIDS.

Peningkatan pengetahuan ini sejalan dengan penelitian yang telah dilakukan oleh Nugrohoi (2014) tentang pengaruh pemberian materi kesehatan reproduksi melalui grup media sosial (facebook) terhadap pengetahuan remaja diperoleh hasil yang signifikan $(0,002, \mathrm{p} \leq 0,05)$. Begitu pula penelitian yang dilakukan oleh Bahari (2014) bahwa media sosial (facebook) dapat meningkatkan pengetahuan tentang kesehatan reproduksi, khususnya alam upaya pencegahan penyakit HIV \&AIDS (Bahari, 2013). Penelitian di luar negeri juga mendukung hal tersebut. Young dkk (2013) mengemukakan bahwa diskusi grup melalui media sosial yakni facebook dapat menjadi forum inovatif untuk meningkatkan pengetahuan tentang pencegahan HIV dan meningkatkan kesadaran untuk tes HIV di antara kelompok berisiko (Young dkk., 2013). Penelitian juga dilakukan oleh 
Aisyah, 2020

Dowshen dkk (2015) di Philadelphia USA. Kampanye kesehatan berbasis media yang bertajuk IknowUshould2 di kalangan remaja berusia 13-17 tahun yang bertujuan untuk meningkatkan pengetahuan tentang HIV \& AIDS dan meningkatkan kesadaran untuk tes sukarela penyakit infeksi menular seksual (IMS) / HIV di klinik keluarga menunjukkan hasil positif (Dowshen dkk., 2015). Salah satu keuntungan diberikannya materi edukasi melalui media sosial adalah aksesibilitas yang tinggi dalam waktu dan tempat, responden dapat mengakses berulangkali informasi tersebut kapanpun dan dimanapun ia berada (Amichai-Hamburger, 2013). Informasi yang diterima responden melalui media sosialnya tersebut memberikan landasan kognitif baru bagi terbentuknya pengetahuan terhadap HIV \& AIDS (Budiman dkk, 2013).

Peningkatan skor rata-rata (mean) responden setelah diberikan intervensi melalui media sosial oleh peer educator juga terjadi pada variabel sikap. Hal ini dibuktikan dengan hasil uji $t$ sampel berpasangan diperoleh nilai $\mathrm{p}=0,000(\mathrm{p}<0,05)$. Nilai $\mathrm{p}$ tersebut bermakna ada perbedaan yang signifikan rerata skor sikap responden pada saat postest dibandingkan saat pretest. Sehingga dapat disimpulkan bahwa ada pengaruh intervensi melalui media sosial oleh peer educator terhadap perubahan sikap positif responden tentang HIV \& AIDS.

Sikap dipengaruhi oleh beberapa faktor diantaranya pengaruh dari sosok yang dianggap penting (Azwar, 2011). Ketika memiliki seseorang yang dianggap penting, maka sikapnya akan konformis atau searah dengannya. Hal ini karena ia memiliki motivasi untuk berafiliasi dan menghindari konflik dengan orang yang dianggap penting tersebut. Perubahan sikap responden pada penelitian ini disebabkan karena pengaruh peer educator yang merupakan sosok penting bagi temannya. Hal ini juga sesuai dengan teori Lapangan (Field Theory) dengan analisis kekuatan medan (force field analysis) dari Kurt Lewin (1951) yaitu bahwa faktor yang mendorong terjadinya perubahan (driving forces) yaitu salah satunya manusia memiliki kebutuhan dasar interpersonal yakni kebutuhan untuk berkumpul bersama-sama dan kebutuhan untuk dikasihi, kedekatan, dan perasaaan emosional. Kebutuhan tersebut dapat dipenuhi dengan melibatkan peer educator atau pendidik sebaya karena seorang rekan adalah orang yang memiliki berbagai kesamaan dalam hal- hal seperti usia, latar belakang, status sosial, dan minat. Peer memainkan peran penting dalam perkembangan psikososial sebagian besar remaja. Faktanya, memberikan kesempatan 
untuk hubungan pribadi, perilaku sosial, dan rasa memiliki. Oleh karena itu, pendidikan sebaya dianggap sebagai salah satu strategi jitu promosi kesehatan pada remaja (Peykari dkk., 2011).

Hasil uji t sampel tidak berpasangan untuk membandingkan variabel pengetahuan antara kelompok intervensi dan kelompok kontrol pada saat pretest diperoleh nilai $\mathrm{p}=0,234(\mathrm{p}$ $>0,05)$. Hal ini menunjukkan bahwa tidak ada perbedaan skor pengetahuan dan sikap antara kelompok intervensi dan kontrol pada saat pretest. Hal ini berarti pengetahuan dan sikap antar kedua kelompok kurang lebih sebanding.

Setelah diuji statistik non parametrik two independent sample (Mann- Whitney), perbandingan variabel pengetahuan antara kelompok intervensi dan kontrol pada saat postest diperoleh nilai $\mathrm{p}=0,000(\mathrm{p}<0,05)$. Artinya ada perbedaan yang signifikan antara perbandingan pengetahuan kelompok intervensi dibandingkan kelompok kontrol setelah dilakukan postest. Hal ini tentu akibat adanya pemberian informasi tentang HIV \& AIDS yang diberikan kepada kelompok intervensi melalui media sosial oleh peer educator. Kelompok intervensi mengalami peningkatan pengetahuan yang signifikan dari pretest ke postes. Namun hal sebaliknya terjadi pada kelompok kontrol yang tidak mengalami perubahan pengetahuan yang signifikan dari pretest ke postest, sehingga ketika hasilnya diperbandingkan ditemukan adanya perbedaan yang signifikan.

Hasil uji $\mathrm{t}$ sampel tidak berpasangan untuk membandingkan sikap antara kelompok intervensi dan kelompok kontrol pada saat pretest menunjukkan nilai $\mathrm{p}=0,765$ $(p>0,05)$. Hal ini bermakna tidak ada perbedaan sikap responden kelompok kontrol dan intervensi. Hasil uji statistik perbandingan sikap antara kelompok intervensi dan kelompok kontrol pada saat postest menunjukkan bahwa nilai $\mathrm{p}=0,000$ $(\mathrm{p}<0,05)$ berarti ada perbedaan sikap yang signifikan.

Sesuai dengan teori S-O-R dari Skinner (1938) bahwa stimulus berupa kata-kata verbal, isyarat non verbal, simbol-simbol tertentu akan merangsang orang (organisme) lain memberikan respon (reaksi) dengan cara tertentu berupa respon tertutup (perubahan pengetahuan dan sikap) serta respon terbuka dalam bentuk perubahan perilaku (Notoadmojo, 2014). Sehingga dapat dinyatakan bahwa sejalan dengan pengetahuan yang tinggi tentang HIV \& AIDS akan menimbulkan sikap yang positif untuk mencegah perilaku seksual berbahaya, menggunakan narkoba, kecanduan pornografi, dan penggunaan benda yang 
Aisyah, 2020

dapat menoreh kulit tanpa disterilkan terlebih dahulu, serta perubahan stigma terhadap penderita HIV \& AIDS.

\section{Keterbatasan Penelitian}

Terdapat berbagai hal yang menjadi keterbatasan pada penelitian ini, diantaranya keterbatasan waktu. Karena pelaksanaan intervensi bertepatan dengan dilaksanakannya ujian semester serta menjelang libur ramadhan. Hal lainnya yaitu adanya faktor perancu (counfounding factor ) yang diluar kuasa peneliti. Faktor tersebut misalnya akses terhadap media selain grup media sosial yang dibentuk, misal informasi tentang HIV \& AIDS dari televisi, surat kabar, orang tua, guru, terutama dari internet.

\section{KESIMPULAN DAN SARAN}

Berdasarkan hasil penelitian dapat disimpulkan bahwa intervensi melalui media sosial oleh peer educator mempengaruhi peningkatan pengetahuan dan sikap positif responden mengenai HIV \& AIDS di Kota Parepare. Metode intervensi melalui media sosial dapat digunakan sebagai strategi untuk menyebarluaskan informasi kesehatan. Strategi ini dapat diterapkan sebagai bentuk promosi kesehatan yang dapat digunakan oleh praktisi kesehatan. Peran peer educator sebagai pendidik bagi teman sebayanya dapat lebih dioptimalkan lagi agar remaja dapat berperilaku sehat, terhindar dari TRIAD KRR (Seksualitas, NAPZA, HIV dan AIDS).

Disarankan kepada Dinas Kependudukan dan Keluarga Berencana Kota Parepare, serta Dinas Pendidikan Provinsi Sulawesi Selatan agar lebih meningkatkan keaktifan Pusat Informasi Konseling Remaja ( PIK -R) dalam hal pemberian pendidikan kesehatan kepada siswa dan lebih meningkatkan keahlian peer educator melalui serangkaian pelatihan. Selain itu hasil penelitian ini dapat lebih dipertajam dan dikembangkan dengan penelitian kualitatif.

\section{DAFTAR PUSTAKA}

Abdi, F. dan Simbar, M. (2013). The Peer Education Approach in AdolescentsNarrative Review Article. Iranian Journal of Public Health, 42(11), hal. 1200-1206.

Amichai-Hamburger, Y. (2013). The Handbook of Intergroup Communication Chapter Reducing Intergroup Conflict In The Digital Age. New York: Routledge.

Azwar, S. (2011). Sikap dan Perilaku Dalam: Sikap Manusia Teori dan Pengukurannya. Yogyakarta: Pustaka Pelajar.

Bahari, D. (2013). Tesis. Promosi Kesehatan. Pascasarjana. Fakultas Kedokteran Universitas Gadjah Mada.

Budiman dan Riyanto, A. (2013). Kuisioner Pengetahuan Dan Sikap Dalam Penelitian Kesehatan. Jakarta: Salemba Medika.

Dinas Kesehatan Kota Parepare. (2017). Laporan Surveilans HIV AIDS di Kota 
Parepare. Parepare: Dinas Kesehatan.

Ditjen P2P Kemenkes RI. (2017). Laporan Situasi Perkembangan HIV-AIDS dan PIMS. Tersedia di: https://www.google.com/search?q=Dit jen+P2P+Kemenkes+RI (Diakses: 10 Februari 2018).

Dowshen, N. et al. (2015). IknowUshould2: Feasibility of a Youth-Driven Social Media Campaign to Promote STI and HIV Testing Among Adolescents in Philadelphia. AIDS Behav, 19(2), hal. 106-111. doi: 10.1007/s10461-0140991-9.IknowUshould2.

Farnan, J. M. et al. (2013). Online Medical Professionalism: Patient and Public Relationships : Policy Statement From the American College of Physicians and the Federation of State Medical Boards. Annals of Internal Medicine, 158(8), hal. 620-627.

George, D. R., Rovniak, L. S. dan Kraschnewski, J. L. (2013). Dangers and opportunities for social media in medicine. Clin Obstet Gynecol, 56(3), hal. 453-462.

Haerana, B. T., Salfiantini dan Ridwan, M. (2015). Peningkatan Pengetahuan Komprehensif HIV dan AIDS melalui Peer Group. Jurnal MKMI, hal. 132138.

Kominfo. (2014). Riset Kominfo dan UNICEF Mengenai Perilaku Anak dan Remaja Dalam Menggunakan Internet. Tersedia di https://kominfo.go.id (Diakses: 1 Februari 2018).

Moshman, D. (2014). Sexuality development in adolescence and beyond : Commentary on arbeit. Human Development, 57(5), hal. 287-291. doi: $10.1159 / 000367857$.

Notoadmojo, S. (2014). Ilmu Perilaku Kesehatan. Jakarta: Rineka Cipta.

Nugrohoi, C. V. (2014). Pengaruh Pemberian Materi Kesehatan Reproduksi Melalui Grup Facebook Terhadap Pengetahuan Remaja. Jurnal Promkes, 2(2), hal.
128-139.

Peykari, N. et al. (2011). An experience of peer education model among medical science university students in Iran. Iranian Journal of Public Health, 40(1), hal. 57-62.

Stang. (2014). Cara Praktis Penentuan Uji Statistik dalam Penelitian Kesehatan dan Kedokteran. Jakarta: Mitra Wacana Media.

Survei Demografi dan Kesehatan Indonesia. (2012). Kesehatan Reproduksi Remaja. Jakarta: Badan Pusat Statistik.

Tolli, M. V. (2012). Effectiveness of peer education interventions for HIV prevention, adolescent pregnancy prevention and sexual health promotion for young people: A systematic review of European studies. Health Education Research, 27(5), hal. 904-913. doi: $10.1093 /$ her/cys055.

WHO. (2017). Global Health Observatory (GHO) HIV/AIDS. Tersedia di: http://www.who.int/gho/hiv/en/ (Diakses: 15 Oktober 2017).

Young, S. D. dan Jaganath, D. (2013). Online Social Networking for HIV Education and Prevention: A Mixed Methods Analysis. Sexually Transmitted Diseases, 40(2), hal. 162-167. doi: 10.1097/OLQ.0b013e318278bd12.Onl ine. 